\title{
ОРГАНІЗАЦІЙНО-ДІЯЛЬНІСНІ ІГРИ ЯК ЗАСІБ РОЗВИТКУ ПІДПРИЄМНИЦЬКОЇ КОМПЕТЕНТНОСТІ МАЙБУТНІХ ЕКОНОМІСТІВ
}

Матукова Г. І. Організаційно-діяльнісні ігри як засіб розвитку підприємницької компетентності майбутніх економістів.

Статтю присвячено опису методики проведення організаційно-діяльнісних ігор, що спрямовуються на особистісний розвиток майбутніх фахівців, набуття ними досвіду міждисциплінарного способу розв'язання професійних проблем. Розкрито зміст організаційно-діяльнісної гри «Регіональний бізнес-проект», проведеної автором у рамках підготовки до міжвузівського конкурсу захисту бізнес-планів задля розвитку компетентності до підприємницької діяльності в майбутніх економістів.

Ключові слова: компетентність до підприємницької діяльності, організаційнодіяльнісна гра, підприємницька компетентність, підготовка майбутніх економістів, міждисциплінарне вирішення професійних проблем.

Матукова А. И. Организационно-деятельностные игры как средство развития предпринимательской компетентности будущих экономистов

Статья посвящена описанию методики проведения организационнодеятельностных игр, которые направлены на личностное развитие будущих специалистов, получение ими опыта междисциплинарного способа решения профессиональных проблем. Раскрыто содержание организационно-деятельностной игры «Региональный бизнес-проект», проведенной автором в рамках подготовки к межвузовскому конкурсу защиты бизнес-планов, с целью развития компетентности к предпринимательской деятельности у будущих экономистов.

Ключевые слова: компетентность в предпринимательской деятельности, организационно-деятельностная игра, предпринимательская компетентность, подготовка будущих экономистов, междисциплинарное решения профессиональных проблем.

Matukova G. I. Organizational and activity games as a means of developing entrepreneurial competence of future economists

The article is devoted to the description of the methodology of the organizational and activity games that are aimed at personal development of future specialists, their experience in an interdisciplinary way to solve professional problems. The author reveals the content of the organizational and activity game "Regional business project" conducted by the author within the framework of preparing for the high school contest of business plans defense with the aim to develop the entrepreneurial activity of future business economists.

Key words: competence in entrepreneurship, organizational and activity game, entrepreneurial competence, training of future economists, interdisciplinary solution to professional problems.

Сучасні науковці і практики небезпідставно відносять гру до одних із поліфункціональних засобів професійного становлення майбутнього фахівця. Гру уважають не лише раціональним, логічним, але і творчо-пізнавальним, інтуїтивно зрозумілим шляхом до здобуття знань, формування професійних компетентностей.

Запропоновано чимало класифікацій ігор, зокрема тих, що $є$ специфічними для бізнес-освіти і професійної підготовки економістів. Ці питання всебічно висвітлюють 
у працях науково-методичного характеру, зокрема О. Аксьонова, Р. Борківська, Я. Галета, О. Керекеша, Г. Ковальчук, I. Прокопенко, I. Сасова, С. Кустовський, О. Пиндик, Г. Романова, Л. Савчук та інші. Дослідники акцентують на необхідності розроблення спеціальних типів ігрової діяльності, здатні забезпечити становлення майбутніх підприємців, конкурентоспроможних на сучасному ринку праці.

3-поміж відомих на сьогодні типів ігор, які застосовуються в системі підготовки та перепідготовки економістів, управлінців, менеджерів різного рівня, особливе місце посідають організаційно-діяльнісні ігри (ОДІ) завдяки винятковим, притаманним лише їм функціям. За структурною ознакою ОДІ корелюють 3 іграми дорослих, науковців, спеціалістів та менеджерів. Почасти ОДІ співвідносні 3 науковими конференціями, мозковим штурмом. Сьогодні ОДІ оперують кількома класами ігрових методів, що знаходять широке застосування і розвиток, це: ділові, рольові, імітаційні й управлінський типи ігор.

Виникнення гри такого типу було зумовлено необхідністю суміжної праці філософської і науково-технічної галузей знань. Проблеми, що виникали в підготовці управлінців та загалом у галузі управління, потребували взаємодії багатьох фахівців із різних галузей суспільного виробництва. Водночас ці професіонали, в силу значної диференціації знань, не могли знайти спільної мови і не зуміли спрацюватися. На заході така ситуація «породила» і розвинула системний підхід. У СРСР цією проблемою опікувалися молоді дослідники філософського факультету Московського державного університету, вони створили Московський методологічний гурток (російською мовою абревіатура ММК), до якого, окрім його фундатора Г. Щедровицького, увійшли О. Зиновьєв, Б. Грушин, М. Мамардашвілі та багато інших відомих науковців. Роботи ММК привели до створення й розвитку системної мисленнєводіяльнісної методології (СМД-методології), де одним 3 основних і провідних компонентів її оволодіння й була організаційно-діяльна гра [3].

Зазначимо, що перший праобраз організаційно-діяльнісної гри виник як результат розв'язання проблемної ситуації економічного гатунку. У 1979 р. Уральська філія Всесоюзного науково-дослідного інституту технічної естетики зштовхнулася 3 завданням розроблення програми дослідження асортиментів товарів народного споживання для Уральського регіону. Завдання ускладнювалося тим, що в цей час, як ми всі розуміємо, панувала планова радянська економіка й порушена проблема не мала відомих рішень і взагалі чи навряд чи могла бути розв'язаною [2].

Зосередження зусиль науковців ММК у напрямі розв'язання цієї ситуації зумовило створення особливого класу ігор. Г. Щедровицький визначив організаційнодіяльнісну гру як нову форму організації колективної розумової діяльності, що дозволяє розв'язувати міждисциплінарні проблеми різних важливих напрямів [3]. Провідною метою ОДІ є збір матеріалів та моделей взаємодії та протидії, розв'язання важливих ситуацій, сценаріїв поведінки у професійній галузі, шляхів побудови стратегій власних дій. При цьому ОДІ володіють ще досить значними перевагами в розвитку найважливіших професійних якостей, що робить їх цінними й задля формування складників професійної компетентності.

Метою статmі є розкриття методики організації та проведення ОДІ, спрямованих на розвиток підприємницької компетентності майбутніх економістів.

Дослідники виокремлюють особливості ОДІ, що відрізняють їх від інших типів ділових ігор, а саме: відносно менш жорсткий сценарій; різноманітний вибір ігрової діяльності, залежно від специфіки проблеми; орієнтація гри на пошук рішень нових, нетривіальні підходів; спрямованість на розвиток і впровадження нових методів колективної творчої роботи [2]. 
При цьому ОДІ, наголошують Т. Водолажська i А. Сгоров, - це не нова альтернатива діловим іграм. Від усіх інших ігор, орієнтованих на розв'язання конкретних предметних завдань або ситуацій, ОДІ вирізняються закладеним у них принципом розвитку. Учасники такої гри не одержують нові знання, а беруть участь у процесі колективного мислення й діяльності з вирішення проблем, тобто самотужки і здобувають, і засвоюють нове знання [2].

В основі концепції такої гри є колективне розв'язання проблемної ситуації в умовах неповної інформації, невизначеності ресурсів. Якщо ж проблема може бути розв'язаною в межах відомих можливостей, усталених підходів, то ОДІ не потрібні. Тут можуть бути використані інші методи, наприклад: ділові ігри, методи управлінського консультування, інтерактивні і продуктивні методи тощо [2].

Організаційно-діяльна гра як особливий метод має дуже широкий спектр можливостей, розв'язуваних завдань, результатів, що досягаються засобами супутніх грі ефектів [2]. В умовах ОДІ виникають, підкреслює О. Анісімов, унікальні можливості для розвитку людини. Тільки через свою активність, проходячи певну кількість етапів розвитку гри, людина набуває нових знань - професійних і загальних. В умовах гри формуються проблемні ситуації, «протистояння між попередніми й теперішніми вимогами». Цінністю ОДІ є те, що в них дії гравців спрямовуються на оволодіння кардинальними нововведеннями, на розвиток практики; і той учасник, що уникає проблемних ситуацій, втрачає можливість набути нових знань й позбавляється перспектив подальшого особистісного й професійного розвитку. У процесі гри, за рахунок обов'язкових фаз рефлексії, відбувається самовизначення відповідно проблемних ситуацій й таким чином відкриваються «двері» процесу саморозвитку [1, с. 375].

Ще один вид завдань, які вкрай рідко пропонуться як головні, але завжди виконуються в ОДІ як супутні - це освіта, навчання, підготовка й підвищення кваліфікації фахівців і особливо керівників. ОДІ, окрім цього, є засобом і методом програмування, проектування і планування діяльності. Логіка їх проведення дає змогу колективу не лише розбиратися 3 нагальними проблемами в діяльності, але i організовувати свою майбутню розумову й практичну роботу. Результат такої роботи може бути оформлений у вигляді проектів, програм, сценаріїв, планів. ОДІ також можуть використовуватися як засіб і метод упровадження інновацій різного роду [2].

Об'єктом організаційно-діяльнісної гри може бути будь-яка проблемна ситуація. Гра проводиться в групах, об'єднаних за принципом кооперації. Склад ігрового колективу, по-перше, орієнтується на рольові позиції в тій діяльності, що імітується в грі. По-друге, для повноти імітації ролі повинні охоплювати основні змістовні або ціннісні опозиції вирішуваної проблеми. Кожна група має власну ігрову мету й з іiі урахуванням включається в загальний робочий процес. Окрім основного складу гравців, у грі є «службові» позиції (керівник гри, методолог, дослідник, ігротехнік), які в комплексі вважаються організаторами гри. Ці позиції не пов'язані безпосередньо зі змістом і темою гри, їх функції полягають у забезпеченні гравців всіма необхідними засобами задля досягнення поставлених ігрових цілей [1]. Їх ми розкриємо далі.

Виокремлюють три великі етапи в проведенні ОДГ: підготовчий, ігровий і рефлексивний [3].

На підготовчому етапі розробляється концепція гри, цілі, які мають бути досягнуті. На цьому ж етапі формується команда, що складається 3 організаторів і ведучих гри; методологів, які відповідають за теоретичну розробку концепції гри та ігротехніків - фахівців, які працюють з групами учасників. У результаті складається регламент і власне оргпроект - список груп, за допомогою якого імітується певна 
сфера діяльності та програма організаційно-діяльнісної гри - поетапне розгортання робочого процесу, розкладеного на дні й форми робіт.

На ігровому етапі реалізується розроблена програма. Цей етап може ділитися на кілька фаз. На першій фазі гри надаються настановні доповіді всім учасникам гри, у яких центральним $є$ виклад концепцій i найважливіших робочих цілей гри із дотриманням регламенту. Далі починається розподіл учасників за групами 3 подальшим розробленням важливих понять відповідно до теми гри. На другій фазі починається входження учасників у гру, організація груп. На наступних фазах проходить робота груп, їх переорганізація, формулюються проміжні висновки.

У ході групової роботи команда взаємодіє з ігротехніком. Він не створює певний продукт, його дії полягають у такому: він організовує знайомство членів команди та сприяє розподілу обов'язків між ними; активує процеси розумової діяльності учасників за рахунок використання методів мозкового штурму, групових дискусій; забезпечує емоційну й інформаційну підтримку гравцям; керує процесами групової динаміки; сприяє підтримці ігрового середовища та довіри між учасниками. У межах гри організатор не змінює поглядів учасників, а лише створює умови задля визначення учасниками своїх недоліків й прийняття правильного рішення; ініціює в них потребу у власних змінах, у пошуку шляхів до нового стану [1;2].

Як процеси самоорганізації, так і процеси саморозвитку в ОДІ забезпечуються переважно за допомогою рефлексії всіх учасників і спеціальної організації рефлексивних процесів у всіх учасників гри. Рефлексія в розглядуваному випадку $є$ важливим методом, що передбачає розумову діяльність, аналіз і самоаналіз. У професійній діяльності вона визначає умови й межі професійних знань і вмінь, у колективній (практичній) роботі, у ході конфліктних ситуацій, вона констатує можливість розумової діяльності. Поєднання практичних процесів із рефлексією $\epsilon$ головним механізмом розумової діяльності учасників гри. Головним для кожного 3 них $є$ удосконалення вмінь аналізувати себе і свою діяльність, переносити тягар колективної праці з інших на себе щодо самокритики, самовизначення в ситуації. У процесі рефлексії кожен має відповісти на питання, що він може і повинен робити в цій ситуації і що він, навпаки, не може і не повинен робити. Якщо учасник гри не може ввійти в рефлексію, сформувати вимоги до себе і своїх здібностей, цінностей й ідеалів, він не зможе зафіксувати для себе ту проблемну ситуацію, яка підштовхне його здібності «щаблями розвитку» вгору. Без якості самовизначення й індивідуальної адекватизації, спрямованості дій на процес розуміння і прийняття можливості розвитку самопізнання, неможливо досягнення ефекту розвитку, уважає один 3 ідеологів ОДІ О. Анісімов [1].

Спеціальному ініціюванню рефлексивних процесів слугує рефлексивний етап, на якому узагальнюється досвід гри. Команда, що розв'язувала проблему, аналізує отриманий досвід і фіксує його в певних формах. Для групи експертів на цьому етапі відбувається узагальнення досвіду й вирішення професійних питань, формування майбутньої стратегії розвитку проблеми. Цей останній етап $є$ по суті етапом виходу 3 гри й узагальненням досвіду, тому розгортається нібито двома паралельними каналами. Це дуже важлива і принципова частина всієї організаційно-діяльнісної гри, що обов'язково повинна проектуватися й прогнозуватися організаторами. Для них третій етап- це завжди етап цілеспрямованого й свідомого рефлексивного й розумового аналізу досвіду проведення гри й фіксація цього досвіду в тих або інших культурно значущих формах - нормативних проектних, методологічних, науководослідних тощо [3].

Програма гри, зазвичай, розрахована на кілька занять (сесій). У програмі гри для 
кожного дня передбачено різні форми роботи. Робота в групах передбачає розв'язання завдань, з урахуванням мети роботи кожної із груп. У результаті групової роботи готуються доповіді, які виносяться на пленарні засідання. Кожен робочий день завершує ігротехнична рефлексія. У програмі гри спеціально передбачено час для індивідуальної роботи й клубного спілкування, i, безумовно, для перерв на обід i сон [2].

Незважаючи на розмаїття ОДІ, вони засновані на поєднанні трьох основних форм: занять у спеціалізованих класах, у профільних, професійних, тематичних та експертних групах, загальних дискусіях всередині команди, рефлексивних занять, групових і загальних.

Отже, у спрощеному вигляді організаційно-діяльнісну гру можна представити як ігрову імітацію певної сфери діяльності, обмеженої в часі й просторі. ОДІ як метод і форма розвитку мислення й діяльності є особливо актуальними і затребуваними в тих суспільних ситуаціях, коли потрібна системна трансформація, тобто перетворення, реорганізація великої кількості складних, комплексних галузей діяльності [2], до яких належить і підприємництво.

У нашому дослідженні ми будемо розуміти під організаційно-діяльнісною грою ігрову імітацію підприємницької діяльності, обмежену в часі та просторі гри, що дозволяє учасникам отримати необхідні компетентності для вирішення тих професійних проблем, що не мають визначених рішень. Вони, за дозованою допомогою організаторів гри, можуть бути знайденими майбутніми фахівцями тільки в умовах спеціально організованої взаємодії між різними професійними позиціями в процесі організації колективного мислення й діяльності, що імітується під час гри [2].

Задля формування в майбутніх фахівців економічного профілю компетентностей до підприємницької діяльності нами було розроблено кілька організаційнодіяльнісних ігор. Далі ми подамо зміст однієї з них.

Організаційно-діяльнісна гра «Регіональний бізнес-проект».

Проблема гри: доцільність малого підприємства на регіональному ринку.

Завдання гри: вивчення сегментів регіонального ринку щодо наявних конкурентів й якості товару; обгрунтування необхідності певного товару на регіональному ринку.

Учасники гри: 3 групи студентів й команда керівників (студентів, викладачів, що виконують ролі - організатора-проектувальника, аналітика, методолога-організатора, спеціалістів і помічників, які будуть здійснювати переміщення, перегрупування учасників, надавати консультативну підтримку командам).

Методи роботи: ділова гра, кейс-метод, дискусія, рейтинг, відео-метод.

Термін проведення: 4 заняття.

\section{ХІД ГРИ \\ 1-заняття}

1. Настановні доповіді організаторів гри, надання учасникам концепції гри, формування підцілей, регламенту:

- доповідь-стимул організатора-проектувальника;

- виступ методолога-організатора, який розтлумачує категорійне поле гри («самовизначення», «рефлексія», «стратегічні і практичні цілі бізнес-проекту» тощо);

- виступ аналітика, який зосереджує увагу на критеріях розвитку підприємницьких компетентностей, можливих утрудненнях у вирішенні професійних завдань, проявах індивідуального й мікрогрупового ставлення до загальної проблеми.

2. Входження учасників до гри, визначення компетентностей студентів, переорганізація (за необхідністю). 
3. Загальна дискусія на тему «Регіональний економічний ринок» за доповіддю організатора-проектувальника. Визначення активнішого учасника.

4. Робота 3 кейсами: вивчення групами підприємств регіону й попиту на ринку основних секторів споживачів.

5. Вільна дискусія. Відповіді організаторів на питання учасників.

\section{2-заняття}

1. Визначення проміжних результатів і поточного рейтингу учасників.

2. Доповіді груп із демонстрацією відеоматеріалів, презентацій: доведення необхідності того чи іншого продукту й підприємства на регіональному Криворізькому ринку; визначення стратегічних, тактичних цілей; побудова матриці можливостей і загроз, баланс сильних і слабких сторін підприємства.

3. Робота в групах: SWOT-аналіз підприємств, визначення асортименту продукції, формування маркетингового аналізу, бюджет витрат на маркетингову діяльність, визначення основних факторів впливу на діяльність підприємства (економічні, ринкові, політичні, технологічні); основних конкурентів та їх часки на ринку, побудова матриці конкурентного профілю.

4. Підбиття проміжних підсумків. За необхідністю, якщо групи студентів виявилися не одного рівня підготовки, переорганізація груп.

5. Підбиття підсумків заняття, доповідь керівника-аналітика щодо представлених досліджень; рейтинг учасників; визначення групами найактивнішого студента, його нагородження - переведення в помічники.

\section{3-заняття}

1. Робота у групах за консультативною підтримкою організаторапроектувальника i помічників: формування виробничого плану, визначення необхідного складу основних засобів, оцінка вартості будівель, споруд, балансової вартості кожного виду основних засобів.

2. Робота у групах із кейсами: визначення площі виробничих приміщень, коригування балансової вартості кожного виду основних засобів на коефіцієнт індексації, розрахунок амортизаційних відрахувань, визначення основних видів ресурсів (матеріали, сировина), постачальників, умов угоди, ціни. Формування колективної доповіді груп щодо використаних методів розрахунку АВ.

3. Конкурс між групами на кращу доповідь щодо виробничого плану регіонального бізнес-проекту. Оцінюється презентація і ступінь обгрунтування розрахункової частини.

4. Узагальнювальні виступи організатора-аналітика й організаторапроектувальника, визначення глибини економічних досліджень групами, обговорення недоліків.

\section{4-заняття}

1. Робота у групах за консультативною підтримкою: розрахунок собівартості продукції, ціни, рентабельності продукції (використання методів на основі витрат i рентабельності), визначення вартості майна, формування науково-дослідної стратегії підприємства, визначення організаційної структури підприємства, необхідної кількості персоналу, оцінка ризиків (види та методи зниження ризиків - технічні, правові, організаційні); формування фінансового плану, визначення точки беззбитковості підприємства.

2. Підготовка проектів до презентації.

3. Презентація проектів з обговоренням.

4. Вільна дискусія «Компетентності бізнес-планування», узагальнення досвіду вирішення професійних проблем. 
5. Діагностика рівнів сформованості професійної компетентності студентів.

6. Підбиття підсумків гри, нагородження групи кращого проекту. Побудова програми втілення у життя визначеного проекту.

7. Обговорення проблеми впровадження проекту 3 усіма студентами, узагальнення результатів гри, виступ організаторів і помічників.

Пропоновану організаційно-діяльнісну гру було проведено як перший відбірковий етап до міжвузівського конкурсу бізнес-проектів. Як результат, гри було представлено три проекти, кращим визнано проект «Солодке життя».

Методологічні підходи до організації та проведення ОДІ орієнтуються на створення зв'язку між мисленням і діяльністю ii учасників у ході вирішення проблеми. Особливість цього класу ігрової діяльності полягає в закладеній в ній можливості до виокремлення власне проблеми, яка, зазвичай, прихована від суб'єкта низкою iї наслідків - перешкодами, утрудненнями тощо. Для того, щоб сформулювати проблему, потрібно здійснити певну мисленнєву роботу, яка спеціально організовується в грі. Складність полягає в тому, що власне проблемні ситуації виникають як суперечності між різними професійними підходами й різними професійними знаннями. Відтак необхідним $є$ вихід учасників гри за межі своєї професійної компетентності до спеціально організованого простору колективного мислення, де й відбувається пошук рішення. Потім відбувається зворотний переклад знайдених рішень не просто в окремі професійні діяльності, а в комплексно організовану діяльність, погоджену й скоординовану [2]. Концепція організаційнодіяльнісної гри надає змогу пройти цей шлях, отримати запроектований результат i при цьому сформувати найцінніші професійні та особистісні якості, отримати нові знання, компетентності, потенції, знайти нові засоби взаємодії. Цьому сприяють закладені в ОДІ правила розгортання миследіяльнісної методології.

\section{Література}

1. Анисимов О. С. Методологическая культура педагогической деятельности и мышления / Олег Сергеевич Анисимов.- М.: Экономика, 1991.- 416 с. 2. Водолажская T. Организационно-деятельностные игры: Популярное введение : монография / Татьяна Водолажская, Андрей Егоров. - Мн. : АГТ-ЦСИ, 2006. - 70 с. 3. Щедровицкий Г.П. Организационно-деятельностная игра: сборник текстов / Георгий Петрович Щедровицкий // Из архива Г. П. Щедровицкого. - Т. 9 (1). - М. : Наука, 2004. - 288 с.

УДК 37.012.8:378

Інеса Новіцька

\section{ФОРМУВАННЯ У МАЙБУТНІХ УЧИТЕЛІВ ПРИРОДНИЧО- МАТЕМАТИЧНИХ ДИСЦИПЛІН ГОТОВНОСТІ ДО РОЗВ'ЯЗАННЯ ПЕДАГОГІЧНИХ ЗАДАЧ}

Новіцька I. В. Формування у майбутніх учителів природничо-математичних дисциплін готовності до розв'язання педагогічних задач.

У статті розглянуто елементи технології формування у майбутніх учителів природничо-математичних дисциплін готовності до розв'язання педагогічних задач. Підсумовано, що під час формування умінь розв'язувати професійні ситуації слід керуватися такими принципами: урахування мотивації студентів, перманентності педагогічної освіти, міждисциплінарного підходу до вивчення загальних, професійних i спеціальних дисциплін, поступового переходу від інформаційного навчання до пошукового й творчого. 3'ясовано, що педагогічні ситуації виконують основні чотири 